\title{
An Assessment of Urban Expansion Impacts on Land Transformation of Rajpur-Sonarpur Municipality
}

\author{
Bijay Halder 1,", Masoud Haghbin ${ }^{2}$, Aitazaz Ahsan Farooque ${ }^{3,4}$ \\ ${ }^{1}$ Department of Remote Sensing and GIS, Vidyasagar University, Midnapore, India \\ ${ }^{2}$ Department of Structural Mechanics \& Hydraulics Engineering, University of Granada, 18001, Granada, Spain; \\ masoudhaghbin@correo.ugr.es \\ ${ }^{3}$ Faculty of Sustainable Design Engineering, University of Prince Edward Island, Charlottetown, PE C1A4P3, Canada; \\ afarooque@upei.ca \\ ${ }^{3}$ School of Climate Change and Adaptation, University of Prince Edward Island, Charlottetown, PE, Canada \\ * Correspondence: halder06bijay@gmail.com
}

Manuscript received: 23-09-2021, revised: 30-11-2021, accepted: 03-12-2021.

\begin{abstract}
Urban expansion, population pressure, and increasing industrialization are influenced the world's natural environment, increased climate change, and global warming. Land use and land cover (LULC) changes are occurring due to anthropogenic activities and the results are land transformation, thermal variation, heat stress, and massive vegetation loss, which is increased oxygen deficiency and air pollution. Remote sensing-based Landsat TM and OLI/TIRS data were used to identify the land transformation and the effect of urbanization in Rajpur-Sonarpur Municipality in the years 2000 and 2020. The Built-up land was increased due to anthropogenic activities and around $12.16 \%$ area has been increased. Similarly, the agricultural land has been increased by $2.10 \mathrm{~km}^{2}$ area and vegetation area has been decreased around $6.52 \mathrm{~km}^{2}$ in the study area. The vegetation degradation areas were located in the South, South-west, and central parts of this study area. Correspondingly, North, North-west and central parts have a noticeable amount of built-up area developed. During twenty years, $6.97^{\circ} \mathrm{C}$ temperature was increased due to urban expansion, population pressure, transportation accessibility, and other urban amenities. The overall accuracies of classification maps were $96.25 \%$ and $91.64 \%$ and the kappa coefficients were 0.95 and 0.89 respectively.
\end{abstract}

Keywords: Urban expansion; land surface temperature; human interaction; geospatial technique; RajpurSonarpur Municipality.

\section{Introduction}

Urbanization processes, population pressure, transportation development, and industrial growth are changing the world economy and environmental conditions like ecosystem imbalance, stability of biodiversity, and thermal variation [1]. Land transformation is the foremost key point of this climate change condition, and this problem has influenced the land surface temperature (LST), which is increased heat stress and environmental degradation [2]. Many parts of the world are losing numerous trees or effects in ecosystems because of urban expansion and vegetation degradation [3]. Vegetation areas are the important factor for controlling the thermal variation in the urban areas, but the overwhelming population pressure, infrastructural development, and industrial works are increased the vegetation degradation in urban areas, which is increased the land surface temperature and urban vulnerability. Moderate-resolution satellite imageries are difficult to use for monitoring the urban areas because of their heterogeneous condition. Landsat data is 30-meter resolution and the pixelbased classification of urban areas increased the problem for monitoring the different classes of LULC. Landsat TM and OLI/TIRS data are 30-meter resolutions and Sentinel-2A data are 10-meter resolutions, but those resolutions are just helped out to build a general study about the urban expansion and vegetation degradation study. A better resolution image is required to build a proper and micro-level study of urban-related studies like urban expansion, land surface temperature variation, LULC change detection, urban heat island (UHI), and urban thermal field variation for ecological study.

The urban expansion significantly influences the land use and land cover change [4]-[6]. The LULC change is increased the climate change scenarios due to earth surface alteration [7], fluctuation of environmental conditions and biodiversity [8], and urban expansion of urban growth [9], [10]. Rapid urban expansion and population pressure have been increased the meteorological impacts on the earth's surface. Many countries are developed new technologies for controlling the climate change impacts on the earth's surface like plantation, 
urban planning, rooftop gardening, awareness, and management. A review of previous studies in this field confirmed that water bodies and vegetation areas are mostly affected by urban expansion and residential pressure [11]-[14].

Land surface temperature refers to the crust temperature of the things that exist on the surface of the earth; it is a direct measure of the hotness of the earth and a direct function of the different categories of LULC classes [15], [16]. The changes in global land surface temperature (LST) and the consequences on the environment have been of great concern to numerous researchers and scientists. The large-scale variation in rural-urban surface temperature has been extensively studied and documented since the 1970s [17]-[19]. The determination of LST is a progressive technique that depends on the use of data retrieved from the Landsat series of the thermal band using air temperature and water vapor [20]. As a significant climate change indicator, LST is also a reflector of the surface heat-energy balance [21]. A scatter plot of LST and vegetation has been created to establish the temperature-vegetation space that portrays the chronological trend of pixels, ranging from low to high temperature-vegetation conditions of urbanization methods [22], [23]. A new way of heat balance model to isolate the anthropogenically settled heat and natural heat radiation from the sensible heat flux has been developed by Kato and Yamaguchi using satellite remote sensing and ground meteorological data [24]. Another study by [25] developed a method that uses both multi-spatial and multi-temporal satellite data to establish the variations in the temperature-vegetation index (TVX) for the monitoring and analysis of urban land use and urban-rural surface temperature conditions. LST is an important surface component that has influenced shortwave surface reflectivity [26]. The highest mean temperature is determined at the highest albedo and impervious surfaces.

One of the easiest ways of estimating the earth surface dynamics on a specific area at different time scales is the remote sensing method. This method depends on remote sensing and GIS techniques to acquire satellite imagery and these images are used as the data for studying the extent of modification of the earth's landscape; they also facilitate the determination of land use pattern dimension (such as the extent of land use, size, and shape of the patches that specify the covered area). Remote Sensing methods can also acquire high-resolution images of different periods of the year to recognize changes in the dynamics of the earth [27]. They are also helpful in regional and environmental planning at the community level. Remotely sensed changes in detection have been reportedly used in the artificial neural network [28], [29]. A new multi-spectral image classification technique has been used to train numerous algorithms; the role is to distinguish pixel-wise transformation in real-time applications. When using satellite images, detection of changes in a scenario is not mostly based on the accuracy of the detection techniques, hence, several algorithms are available for more accurate detection of the changes on the surface of the earth. The lithosphere is a term used to describe the total land use and the land cover area; the land cover area includes vegetation and water bodies. Human demands are recently changing due to advancements in technologies, increased access to urban facilities, and changes in human existence. To meet these demands, new structures and infrastructures, such as flats, complexes, roads, and other urban facilities are being constructed, thereby increasing the land use area. Researchers have noticed and reported the gradual and systematic changes on earth and the other spatial and temporal variations of the earth [30], [31].

Remote sensing and GIS techniques were widely used to monitor the land use and land cover (LULC) change detection, mapping, and monitoring the land dynamics over the area. Satellite image-based land transformation study is the main reason for focusing the land used policymaking and land dynamic study[32], [33]. Spectral indicators like Normalize Difference Vegetation Index (NDVI) and Normalize Difference Builtup Index (NDBI) are used for monitoring the vegetation scenario and built-up expansion over the RajpurSonarpur municipality area. The Peripheral part of the megacity is influenced by the oxygen balance, sufficient trees cover, and many other opportunities but population pressure can change the environmental condition and influences the natural ecological condition in the study area. The main objective of this study is to find out that, (1) LULC change in the study area during 2000 to 2020; (2) NDVI generation for vegetation area identification and vegetation health monitoring; (3) NDBI generation for identification of built-up expansion in the study area; (4) Urban green space area identification in the Rajpur-Sonarpur Municipality area and (5) suggest some strategies to improve the urban environment and management planning. This study may be helpful for the local administrative, urban planners, and other stakeholders to build proper planning and management for sustainable development and healthy life. This work is more useful for the planning and monitoring purpose also the UTFVI and UHI maps are indicated the urban expansion and the impact of the earth's surface. These research outputs have increased the visibility of Rajpur-Sonarpur Municipality land alteration, which has not been examined before with the help of UTFVI, UHI, LST, and different spectral indicators.

\section{Study area}

The Rajpur-Sonarpur Municipality area is designated for the study area, which is situated in the South 24 Parganas district of West Bengal, India (Figure 1). Rajpur-Sonarpur municipality was established in the year 1980 and is located in the southern part of megacity Kolkata. Now, this municipality has been 35 (thirty-five) 
wards of their municipality area. Around $49.25 \mathrm{~km}^{2}$ area is covered by Rajpur-Sonarpur Municipality (https://www.rajpursonarpurmunicipality.in). The overall population of this municipality was 4.24 lakhs (District Census Handbook, South 24 Parganas, 2011). Rajpur-Sonarpur Municipality had a 106604 household and an increasing household in this area [34]. The study area is located $88^{\circ} 20^{\prime} \mathrm{E}$ to $88^{\circ} 27^{\prime} \mathrm{E}$ and $22^{\circ} 23^{\prime} \mathrm{N}$ to $22^{\circ} 29^{\prime} \mathrm{N}$. The Main major sources of transportations are railway, bus, auto, and rickshaw. Private cars and bikes are also the reason for traffic congestion in this study area. The Sonarpur railway station is the main source of transportation, which is directly joint with the Sealdha station (One of the main railway junctions of Kolkata). The Rajpur-Sonarpur municipality area is used for this study because the peripheral part is mostly affected by urban expansion, population pressure. Agricultural land and vegetation area are decreased due to urban expansion and increased food scarcity and environmental degradation. The Rajpur-Sonarpur municipality is affected by UHI and heat stress, which is increased urban vulnerability. The megacity Kolkata is located in the upper parts of this study area and increasing population pressure was spread-out in this municipality and increased the natural environment, that's why this study area is chosen for identifying the urban expansion scenarios and green space deficiency using remote sensing and GIS.

Before the State Highway 1 (also known as E. M. Bypass) project Rajpur-Sonarpur municipality was connected to Kolkata by N.S.C Bose Road (Netaji Subhash Chandra Bose Road) and Garia Main Road. This is a dream of the distant past now after the construction of State Highway 1 (SH-1) and the Eastern Metropolitan Bypass easily connecting the place with the heart of Kolkata. Another State Highway is Diamond Harbour Main Road. The total elevation of this area is $9 \mathrm{~m}$. Near river Bhagirathi-Hoogly and the entire area situated in Ganga Delta. The elevation is 9 meters and the area is under Kolkata Metropolitan Development Authority (KMDA). Rajpur and Sonarpur are the two main towns, after establishing the municipality those areas are called RajpurSonarpur Municipality. The population density of this area is $8600 \mathrm{~km}^{2}$ or $22000 \mathrm{~m}^{2}$ (Census of India, https://censusindia.gov.in/).

\section{Materials and method}

\subsection{Data used}

Land use and land cover (LULC) alteration or dynamics were analysed and monitored using Landsat TM and OLI/TIRS images. Different years (2000 and 2020) imageries were used to identify the actual change scenario for the earth surface of Rajpur-Sonarpur Municipality, West Bengal, India (https://earthexplorer.usgs.gov/) with the least clouds and snow cover $<10 \%$. 2000- and 2020-year images were taken for LULC change detection and detect the LST change and urban green space-changing scenario with 30-meter resolution. For a well understanding of the LST and green space of this area, the 2020 satellite image was deliberately included in this area despite a difference in the time interval. The selected satellite imageries information was shown in Table 1. The Population data, administrative boundary, and total Rajpur-Sonarpur Municipality of this study area were derived from the Census of India (https://censusindia.gov.in/). Population data were derived from the Census of India 2011 for urban heat stress map. Google Earth data and field survey data were used for validation of the results. Supervised classification and maximum likelihood algorithm are used to classify the satellite images and delineation of the LULC change dynamics identification over the study area (Figure 2). Supervised classification technique is more useful for monitoring the land classification and alteration using signature values. Researchers can use signature data and field data was used for validating purposes. Unsupervised classification is not a signature-based classification, that's why supervised classification is used for this study. 

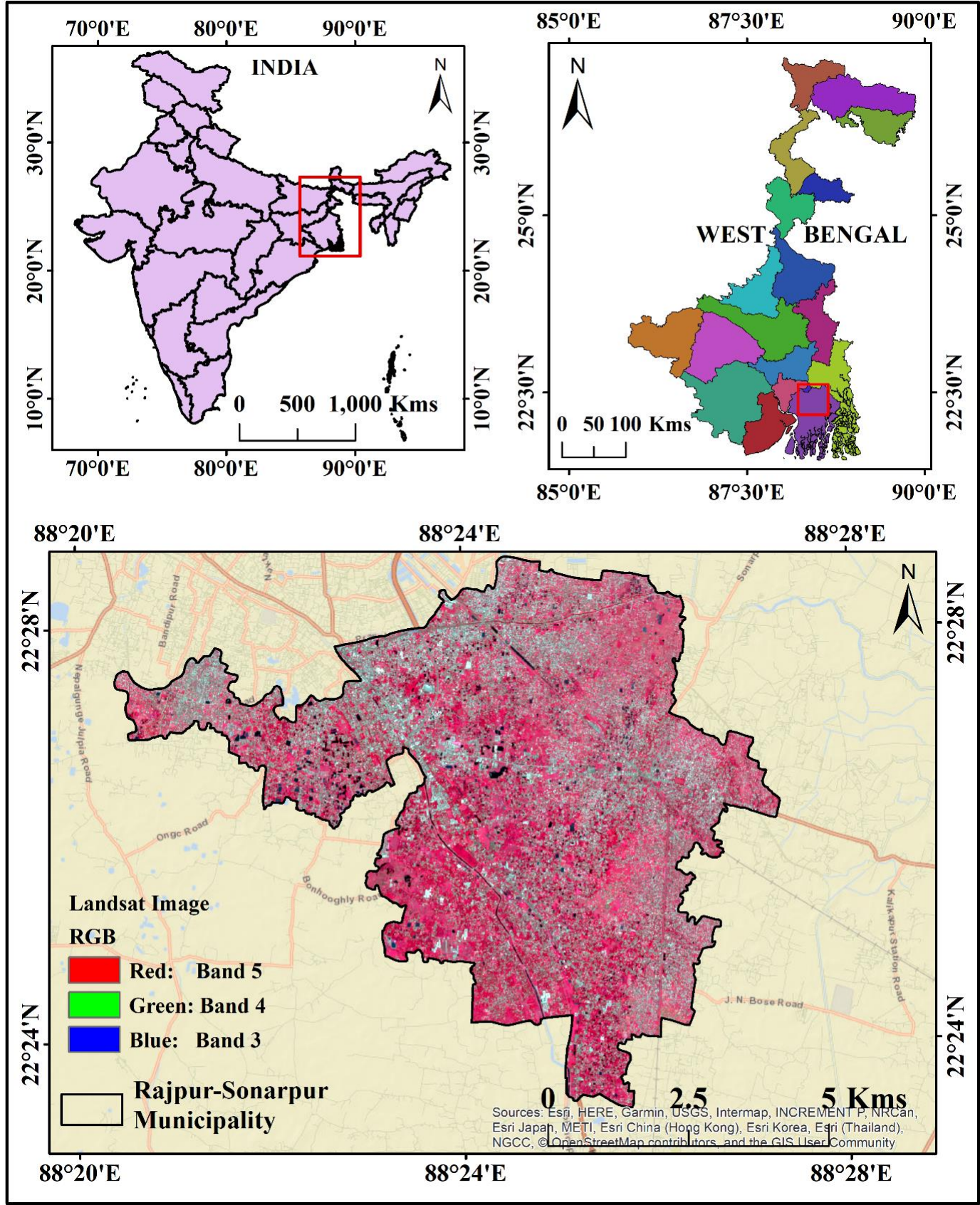

Figure 1. Locational map of this study.

Table 1. Model performance and error statistics.

\begin{tabular}{|c|c|c|c|}
\hline Data /Sensor & Date & Path and Row & Data acquisition \\
\hline Landsat 5 TM & $09-11-2000$ & $138 ; 44$ & $\underline{\mathrm{https}: / / \text { earthexplorer.usgs.gov/ }}$ \\
\hline Landsat 8 OLI/TIRS & $18-12-2020$ & $138 ; 44$ & $\underline{\mathrm{https}: / / \text { earthexplorer.usgs.gov/ }}$ \\
\hline
\end{tabular}




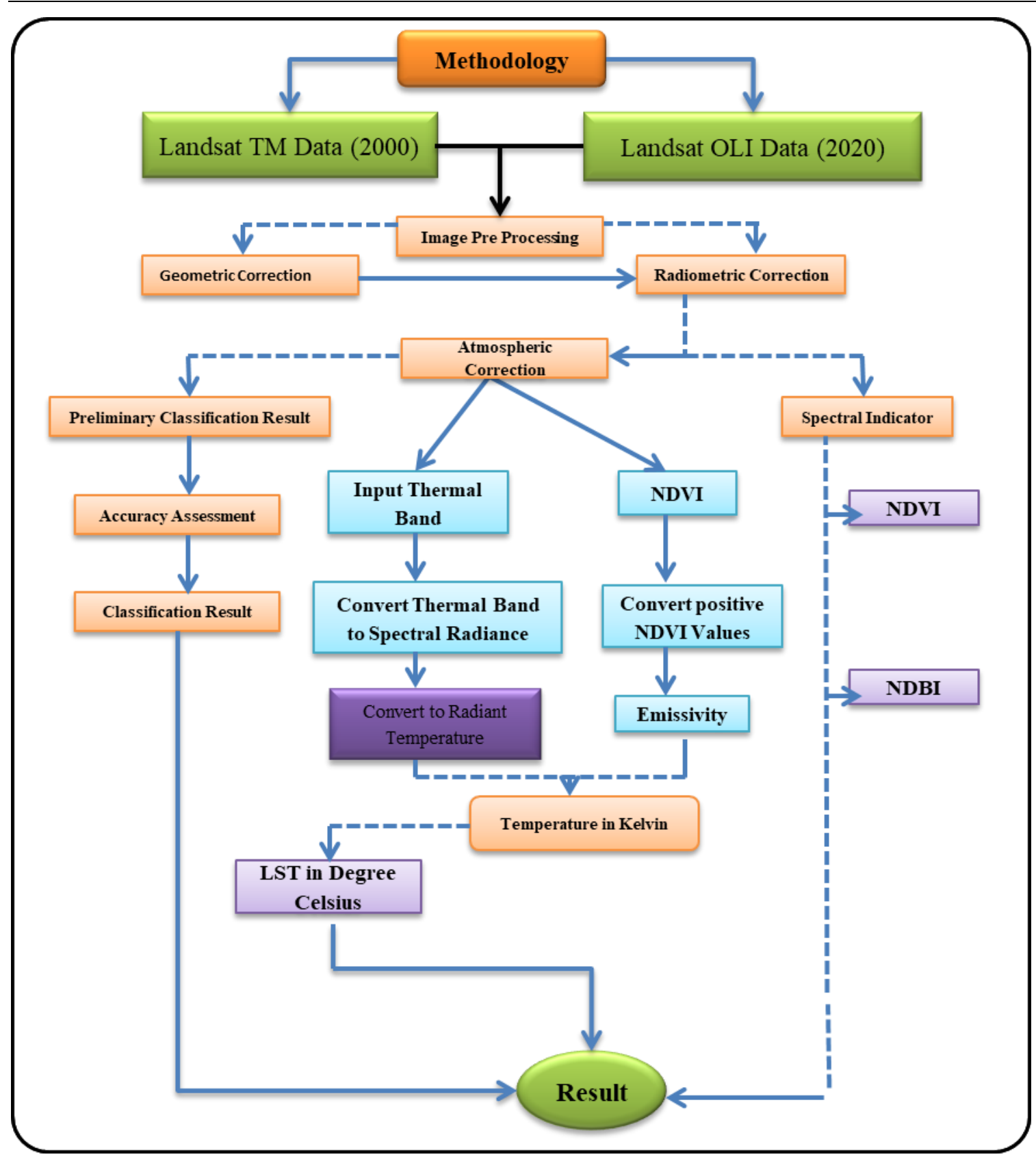

Figure 2. Details methodology of this study.

\subsection{Pre-processing and classification}

The remote sensing-based satellite data were pre-processed to detect the LULC classification and extract the agricultural land, vegetation, and built-up land of the study area for the years 2000 and 2020. With the minimal alteration of the geometric accuracy, the satellite data were collected from 2000 and 2020. For better quality of the satellite datasets, images were enhanced using histogram equalization [35]. To remove the image distortion, remote sensing-based satellite data were re-projected into World Geodetic System (WGS) 1984 Universal Transverse Mercator (UTM) zone 45 N. Satellite data were pre-processed in ERDAS IMAGINE version14 and ArcGIS version 10.5 and then geo-referenced, atmospheric correction, radiometric correction and finally subsisting Region of Interest (ROI) on notified software. A post-classification change detection technique was calculated in ERDAS IMAGINE version 14 software. Many researchers were used to detecting the actual change of the rural environmental area or natural location and rate of change [10]-[13]. The Change detection technique is used for monitoring the land alteration of the earth's surface, which is calculated on a 'pixel by pixel basis and identifying the change of LULC classes [36]. 


\subsection{Accuracy Assessment and kappa coefficient}

After image classification, accuracy assessment is the important factor for monitoring the accuracy of the classification image [37]. The different year satellite data like Landsat TM and OLI/TIRS are used for monitoring the LULC change and vegetation monitoring of the study area [38]. Remote sensing software (ERDAS IMAGINE v14 and ArcGIS v10.5) was used for the accuracy assessment. Accuracy assessment is a technique, which represents the correspondence between the aspect of the earth's surface and the results of the classification. It is exact significant to distinguish the impeccable accuracy by the appropriate classification of different year satellite imageries to analyse the land-use and land cover (LULC) changes [39]. The accuracy assessment of the land use and land cover (LULC) maps were checked using the round truth data and the results were interpreted using overall accuracy (OA) and kappa coefficient $\left(k_{i}\right)$ (Table 2$)$, which are shown in equtions1 and 2.

$$
\begin{gathered}
O A=\left(\frac{\sum_{i=1}^{k} n_{i j}}{n}\right) \\
K_{i}=\frac{(\text { Observed accuracy }- \text { Chance accuracy })}{(1-\text { Chance accuracy })}
\end{gathered}
$$

where, $n_{i j}$ is representing the diagonal elements in the error matrix, $k$ is total number of classes in the LULC classification, $\mathrm{n}$ is total number of samples in the error matrix, and $K_{i}$ represents the kappa coefficient. Observed accuracy indicated the corrected signature of the classification and change accuracy indicates the misclassified pixels.

Table 2. The scale of kappa coefficient.

\begin{tabular}{|c|c|c|}
\hline Sl No. & Value of K & Strength of agreement \\
\hline $\mathbf{1}$ & $<0.20$ & Poor \\
\hline $\mathbf{2}$ & $0.21-0.40$ & Fair \\
\hline $\mathbf{3}$ & $0.41-0.60$ & Moderate \\
\hline $\mathbf{4}$ & $0.61-0.80$ & Good \\
\hline $\mathbf{5}$ & $0.81-1.00$ & Very good \\
\hline
\end{tabular}

\subsection{LULC change detection and validation}

Land cover (LC) is the natural earth surface topographies that is growing naturally, like vegetation coverage, water bodies, agricultural land, etc. the land use and land cover (LULC) change examination is additionally significant to classifying the agricultural land or any land use and land cover along with the built-up area over the study region using different periods [40], [41]. The rural fringe area, population pressure, and industrialization were hammering the natural land cover area and affecting the vegetation cover, agricultural land, etc. The supervised classification method with the maximum likelihood algorithm was used to classify the land use/land cover (LULC) dynamics investigation using different year Landsat TM and OLI/TIRS to conduct multitemporal LULC classification [42]. The areas were classified into six classes, built-up area, vegetation, agricultural land, waterbody/ pond, grassland, and open space over this study area. The accuracy assessment and kappa coefficient were calculated in ERDAS to Imagine software v.14; the accuracy toolbar was used to identify the accuracy assessment of the classification (Table 3). Google Earth field survey data were used for accuracy assessment. The points were collected from the Google Earth platform according to the Landsat TM and OLI/TIRS images acquisition data.

Table 3. Details of LULC class identification in satellite images.

\begin{tabular}{|c|c|c|}
\hline SI No. & LULC classes & Description \\
\hline $\mathbf{1}$ & Built-up Area & $\begin{array}{c}\text { Residential area, commercial, industrial, transportations, roads, and } \\
\text { construction area. }\end{array}$ \\
\hline $\mathbf{2}$ & Vegetation & An area having plantation or natural growing forest, it is including \\
& & \begin{tabular}{c} 
many types of trees. \\
\hline
\end{tabular}
\end{tabular}


KBES 2021, 2, 3

\begin{tabular}{|c|c|c|}
\hline $\mathbf{3}$ & Open Space & $\begin{array}{c}\text { These types of classes are mainly playground, open area, and many } \\
\text { others. }\end{array}$ \\
\hline $\mathbf{4}$ & Water Bodies & River, Pond, lakes, and open water area. \\
\hline $\mathbf{5}$ & Agricultural Land & Cropland and fallow land of this area. \\
\hline $\mathbf{6}$ & Grassland & Grasses area identified in satellite images. \\
\hline
\end{tabular}

\subsection{LST calculation}

\subsubsection{LST for Landsat TM}

The Land Surface Temperature (LST) was calculated using some notified formula (Eq. 3-7) [43]. The steps of LST calculation for Landsat Thematic Mapper are (Eq. 3-7).

i. Conversion of the digital number (DN) to the spectral radiance (L) (USGS 2001) is calculated by Eq. 3.

$$
L=\left(\frac{L_{\max }-L_{\min }}{D N_{\max }}\right) \times \text { Band }+L_{\min }
$$

where $\mathrm{L}$ is that the spectral radiance, $L_{\min }$ is that the 1.238 (The spectral radiance of the $D N$ value 1 ), $L_{\max }$ is that the 15.6000 (The spectral radiance of $D N$ value 255), and $D N$ is that the digital number.

ii. Conversion of spectral radiance to temperature in kelvin (USGS 2001) is calculated by Eq. 4.

$$
T b=\frac{K 2}{\left(\frac{K 1}{L \lambda}+1\right)}
$$

where, $K 1$ id the calibration constant 1 (607.76), $K 2$ is that the calibration constant $2(1260.56)$, and $T b$ is that the surface temperature (kelvin).

iii. Calculation of NDVI

$$
N D V I=\frac{(N I R-R)}{(N I R+R)}
$$

Land surface emissivity (LSE) is calculated based in NDVI values. It used the NDVI Thresholds MethodNDVITHM by applying the Eq. 6 [44].

$$
L S E=(1.0094+0.047) \times \operatorname{In}(N D V I)
$$

The NDVI value range from 0.157 to 0.727 . When the NDVI values are out of the range (0.157 to 0.727$)$, the corresponding input LST constant values are used.

iv. Conversion of Kelvin to Celsius [45] is estimated by Eq 7.

$$
L S T=T b-273.15
$$

\subsubsection{LST for Landsat OLI}

i. Conversion of the Digital Number (DN) to spectral radiance (L) [15], [46], [47] is calculated by Eq. 8.

$$
L=\left(\frac{L_{\max }-L_{\text {min }}}{D N_{\max }}\right) \times \text { Band }+L_{\text {min }}
$$

where, $\mathrm{L}=$ Atmospheric spectral radiance $(\mathrm{SR})$ in watts $/\left(\mathrm{m}^{2 *} \mathrm{srad}^{*} \mu \mathrm{m}\right), \mathrm{L}_{\max }=$ Maximum spectral radiance $(\mathrm{SR})$ of the $\mathrm{DN}$ value, BandL $\mathrm{L}_{\min }$ Minimum spectral radiance $(\mathrm{SR})$ of $\mathrm{Band}, \mathrm{DN}_{\max }=\mathrm{Q}$ cal max $-\mathrm{Q}$ cal min $=$ maximum and minimum difference of sensor calibration.

ii. Using the thermal constants given in the metadata file, the TIRS band data has converted from SR to BT once the DN value are converted to SR [48] (Eq.9).

$$
B T=\frac{K 2}{\operatorname{Ln}\left(\frac{K 1}{L \lambda}+1\right)}-273.15
$$

where, $B T=$ Brightness temperature in Celsius. $K_{2}$ and $K_{1}$ represents the band-specific thermal conversion constants,

iii. Calculation of Normalized Different Vegetation Index (NDVI) [15], [49] (Eq.10):

$$
N D V I=\frac{(N I R-R)}{(N I R+R)}
$$

where, the Range of NDVI changes -1 to +1 . 
iv. Proportion of Vegetation is calculated by minimum and maximum NDVI value [50]. The Equation is (Eq.11)

$$
P v=\left(\frac{N D V I-N D V I_{\min }}{N D V I_{\max }-N D V I_{\min }}\right)^{2}
$$

v. Land surface emissivity $(L S E)$ is calculated based $P_{v}$ Value. It used the NDVI Thresholds MethodNDVITHM by applying the Eq. 12 [51], [52].

$$
L S E=0.004 \times P v+0.986
$$

vi. Conversion of Kelvin to Celsius [51], [52] is estimated by Eq.13

$$
L S T=\frac{B T}{\left\{1+\left[\frac{\lambda \mathrm{BT}}{\rho}\right] \operatorname{In}(\mathrm{LSE})\right.}
$$

where $\lambda=$ the wavelength of emitted radiance.

\section{Spectral indicators}

Different spectral indicators were derived from satellite imageries (Landsat TM and OLI/TIRS) in different years for delineating the vegetation degradation and built-up expansion of this study area. The spectral indicators have been calculated by the notified formula. The spectral indicators are explained in the following subsections.

\subsection{Normalized Difference Vegetation Index (NDVI)}

Vegetation is an essential component of the earth's land cover; soil erosion and flooding are less severe in areas with healthy vegetation. Vegetation also creates a balance between the oxygen cycle and carbon dioxide cycle; however, vegetation is affected by changes in weather conditions [53]. About 33\% of the total land area in India is covered with vegetation as it is essential for healthy living. The quality and quantity of vegetation in any area can be determined from the Normalized Difference Vegetation Index (NDVI). In India, the extent of degradation or vegetation in the South Parganas district has been identified from the vegetation quality (NDVI) map in a previous study [15]. As a multi-spectral remote sensing data approach, the NDVI can identify and classify land cover, vegetation area, water bodies, open areas, and forest areas. The NDVI is mathematically calculated and the value ranges from -1.0 to +1.0 . For water bodies, the calculated NDVI values are in the negative range (see Eq. 14):

$$
N D V I=\frac{(N I R-R)}{(N I R+R)}
$$

where NIR is near-infrared and $\mathrm{R}$ is red band in the satellite image). Calculations for the damaged vegetation area are based on the Landsat TM and OLI/TIRS. The change detection technique is the best remote sensing technique for the detection of aerial changes in the vegetation-covered areas and vegetation to the nonvegetation area or non-vegetation to vegetation area.

\subsection{Normalized Difference Built-up Index (NDBI)}

Normalized Difference Built-up Index (NDBI) is calculated for the urban area identification where Landsat 8 OLI shortwave infrared (SWIR) is characteristically higher reflectance compared to the near-infrared region. This built-up index (Eq.15) is used for built-up area and land use planning [38]:

$$
N D B I=\frac{(S W I R-N I R)}{(S W I R+N I R)}
$$

NDBI is described that the value between -1.0 to +1.0 . Built-up area is detected in Normalized Difference Built-up Index (NDBI) values are that the positive values are shown.

\section{Green space area identification}

The urban expansion is triggered vegetation degradation and increased the urban thermal variation. The figures were clearly shown that the vegetation areas were cut down for urban expansion and other anthropogenic activities over the study area. The main roads area showed that low vegetated land, cut down and commove of old trees were the natural thing to build a sustainable development of this study area. Transportation systems and public vehicles were the main reasons for urban expansion and vegetation degradation in the study area. 
Old trees were removed, and new trees were planted near the main road and housing complex from 2000 to 2020. Climate change was affected in the study area because of the huge amount of transportation systems, anthropogenic activities, and urban expansion. Temperature also increased during master area planning time. Vegetation degradation, removal, and cut down were the main reasons for air pollution and heat variation in the summertime. The vegetation area shadow helps the people for providing relief for direct solar thermal heating during the summer season.

\section{Urban thermal field variation index (UTFVI)}

Urban thermal field variation index (UTFVI) is used for monitoring the ecological condition which is affected by the urban heat island effect and thermal variation [52]. UTFVI is widely used for monitoring the change of ecological conditions of the urban area. The heat wave, heat stress, psychometric, illumination intensity, and modification of the earth's surface. The formula for calculating the UTFVI is

$$
\text { UTFVI }=\left(\frac{T_{s}-T_{\text {mean }}}{T_{\text {mean }}}\right)
$$

where, UHFVI= Urban Thermal Field Variation Index; $\mathrm{T}_{\mathrm{s}}=$ Land surface temperature $(\mathrm{LST})$ in kelvin; $\mathrm{T}_{\text {mean }}=$ Mean LST in Kelvin. The UHI influence the ecological condition of the urban area and UTFVI can be calculated separate six levels with six different ecological conditions.

\subsection{Urban Heat island (UHI)}

The urban heat island assessment is the most effective study for monitoring the thermal variation and heat stress in the urban area. To identify the UHI in urban areas the notified formula was used (Equation.13).

$$
U H I=\left(\frac{T_{s}-T_{\text {mean }}}{S D}\right)
$$

where, $\mathrm{UHI}=$ Urban heat island; $\mathrm{T}_{\mathrm{s}}=$ Land surface temperature (LST) in kelvin; $\mathrm{T}_{\text {mean }}=$ Mean LST in Kelvin; $\mathrm{SD}=$ standard deviation which is calculated from the LST maps of different periods.

\section{Result and discussion}

\subsection{LULC classification and change analysis}

The LULC alteration analysis is an important factor for monitoring the earth's surface change and also the thermal variation of the study area. The overall accuracy was 96.25 (2000) and $91.64 \%$ (2020) and the kappa coefficient was 0.95 (2000) and 0.89 (2020). Tables 4 and 5 show that the overall accuracy and kappa coefficient of LULC classification. The $5.99 \mathrm{~km}^{2}$ of built-up land was increased in the Rajpur-Sonarpur Municipality and vegetation areas are decreased by around $6.52 \mathrm{~km}^{2}$, similarly, the agricultural land also increased $\left(2.3 \mathrm{~km}^{2}\right) \mathrm{due}$ to anthropogenic activities and population pressure. Agricultural land is the key source for the local farmers for cultivation, which is increased due to vegetation degradation and population pressure. Table 6 shows the classification area calculation over the study area and Figures 3 and 4 show that classification maps and graphical representations of the area. The built-up area has been increased $12.16 \%$ from 2000 to 2020 and similarly the vegetation land (13.24\%) and grassland (0.71\%) were decreased in Rajpur-Sonarpur Municipality. Urban expansion and anthropogenic activities were the reason for vegetation degradation and ecological change. Agricultural land has been increased by $4.26 \%$ area because of the high rate of vegetation area was converted into agricultural land.

Table 4. Accuracy assessment and kappa coefficient of 2000.

\begin{tabular}{|c|c|c|c|c|c|c|c|c|c|}
\hline & \multicolumn{7}{|c|}{ Ground Truth/Reference } & \multirow{2}{*}{ Row } & Commissio \\
\cline { 2 - 8 } Class Name & $\begin{array}{c}\text { Water } \\
\text { Body }\end{array}$ & $\begin{array}{c}\text { Agricultura } \\
\text { I Land }\end{array}$ & $\begin{array}{c}\text { Tree or } \\
\text { Vegetatio } \\
\mathbf{n}\end{array}$ & $\begin{array}{c}\text { Open } \\
\text { space }\end{array}$ & $\begin{array}{c}\text { Grass } \\
\text { Land }\end{array}$ & $\begin{array}{c}\text { Built-up } \\
\text { Land }\end{array}$ & $\begin{array}{c}\text { Total } \\
\text { T Error }\end{array}$ & Accuracy \\
\hline $\begin{array}{c}\text { Water } \\
\text { Body }\end{array}$ & 63 & 0 & 0 & 2 & 0 & 0 & 65 & $3.08 \%$ & $96.92 \%$ \\
\hline $\begin{array}{c}\text { Agricultura } \\
\text { I Land }\end{array}$ & 0 & 125 & 1 & 2 & 0 & 1 & 129 & $3.10 \%$ & $96.90 \%$ \\
\hline $\begin{array}{c}\text { Tree or } \\
\text { Vegetation }\end{array}$ & 0 & 0 & 39 & 1 & 0 & 1 & 41 & $4.88 \%$ & $95.12 \%$ \\
\hline
\end{tabular}


KBES 2021, 2, 3

\begin{tabular}{|c|c|c|c|c|c|c|c|c|c|}
\hline Open space & 1 & 0 & 1 & 51 & 0 & 0 & 53 & $3.77 \%$ & $96.23 \%$ \\
\hline Grass Land & 0 & 0 & 0 & 1 & 57 & 1 & 59 & $3.39 \%$ & $96.61 \%$ \\
\hline $\begin{array}{c}\text { Built-up } \\
\text { land }\end{array}$ & 2 & 1 & 0 & 0 & 0 & 50 & 53 & $5.66 \%$ & $94.34 \%$ \\
\hline $\begin{array}{c}\text { Column } \\
\text { Total }\end{array}$ & 66 & 126 & 41 & 57 & 57 & 53 & 400 & & \\
\hline $\begin{array}{c}\text { Omission } \\
\text { Error }\end{array}$ & $4.55 \%$ & $0.79 \%$ & $4.88 \%$ & $10.53 \%$ & $0.00 \%$ & $5.66 \%$ & & & \\
\hline $\begin{array}{c}\text { Produce } \\
\text { Accuracy }\end{array}$ & $95.45 \%$ & $99.21 \%$ & $95.12 \%$ & $89.47 \%$ & $100.00 \%$ & $94.34 \%$ & & & \\
\hline $\begin{array}{c}\text { Overall } \\
\text { Accuracy }\end{array}$ & $\begin{array}{c}\mathbf{9 6 . 2 5} \\
\mathbf{9}\end{array}$ & & & $\begin{array}{c}\text { Kappa } \\
\text { Coefficient }\end{array}$ & $\mathbf{0 . 9 5}$ & & & \\
\hline
\end{tabular}

Table 5. Accuracy assessment and kappa coefficient of 2020.

\begin{tabular}{|c|c|c|c|c|c|c|c|c|c|}
\hline \multirow[b]{2}{*}{ Class Name } & \multicolumn{6}{|c|}{ Ground Truth/Reference } & \multirow{2}{*}{$\begin{array}{l}\text { Row } \\
\text { Total }\end{array}$} & \multirow{2}{*}{$\begin{array}{c}\text { Commission } \\
\text { Error }\end{array}$} & \multirow{2}{*}{$\begin{array}{c}\text { User } \\
\text { Accuracy }\end{array}$} \\
\hline & $\begin{array}{l}\text { Water } \\
\text { Body }\end{array}$ & $\begin{array}{c}\text { Agricultural } \\
\text { Land }\end{array}$ & $\begin{array}{c}\text { Tree or } \\
\text { vegetation }\end{array}$ & $\begin{array}{l}\text { Open } \\
\text { Space }\end{array}$ & $\begin{array}{l}\text { Grass } \\
\text { Land }\end{array}$ & $\begin{array}{c}\text { Built-up } \\
\text { land }\end{array}$ & & & \\
\hline Water Body & 33 & 1 & 1 & 1 & 1 & 0 & 37 & $10.81 \%$ & $89.19 \%$ \\
\hline $\begin{array}{c}\text { Agricultural } \\
\text { Land }\end{array}$ & 1 & 35 & 0 & 1 & 2 & 0 & 39 & $10.26 \%$ & $89.74 \%$ \\
\hline $\begin{array}{c}\text { Tree or } \\
\text { vegetation }\end{array}$ & 1 & 0 & 99 & 2 & 1 & 2 & 105 & $5.71 \%$ & $94.29 \%$ \\
\hline Open Space & 1 & 1 & 1 & 24 & 0 & 1 & 28 & $14.29 \%$ & $85.71 \%$ \\
\hline Grass Land & 0 & 1 & 1 & 1 & 16 & 0 & 19 & $15.79 \%$ & $84.21 \%$ \\
\hline $\begin{array}{c}\text { Built-up } \\
\text { land }\end{array}$ & 1 & 0 & 2 & 2 & 1 & 89 & 95 & $6.32 \%$ & $93.68 \%$ \\
\hline $\begin{array}{c}\text { Column } \\
\text { Total } \\
\end{array}$ & 37 & 38 & 104 & 31 & 21 & 92 & 323 & & \\
\hline $\begin{array}{c}\text { Omission } \\
\text { Error }\end{array}$ & $10.81 \%$ & $7.89 \%$ & $4.81 \%$ & $22.58 \%$ & $23.81 \%$ & & & & \\
\hline $\begin{array}{l}\text { Produce } \\
\text { Accuracy }\end{array}$ & $89.19 \%$ & $92.11 \%$ & $95.19 \%$ & $77.42 \%$ & $76.19 \%$ & & & & \\
\hline $\begin{array}{c}\text { Overall } \\
\text { Accuracy }\end{array}$ & $91.64 \%$ & & & & & $\begin{array}{c}\text { Kappa } \\
\text { Coefficient }\end{array}$ & 0.89 & & \\
\hline
\end{tabular}

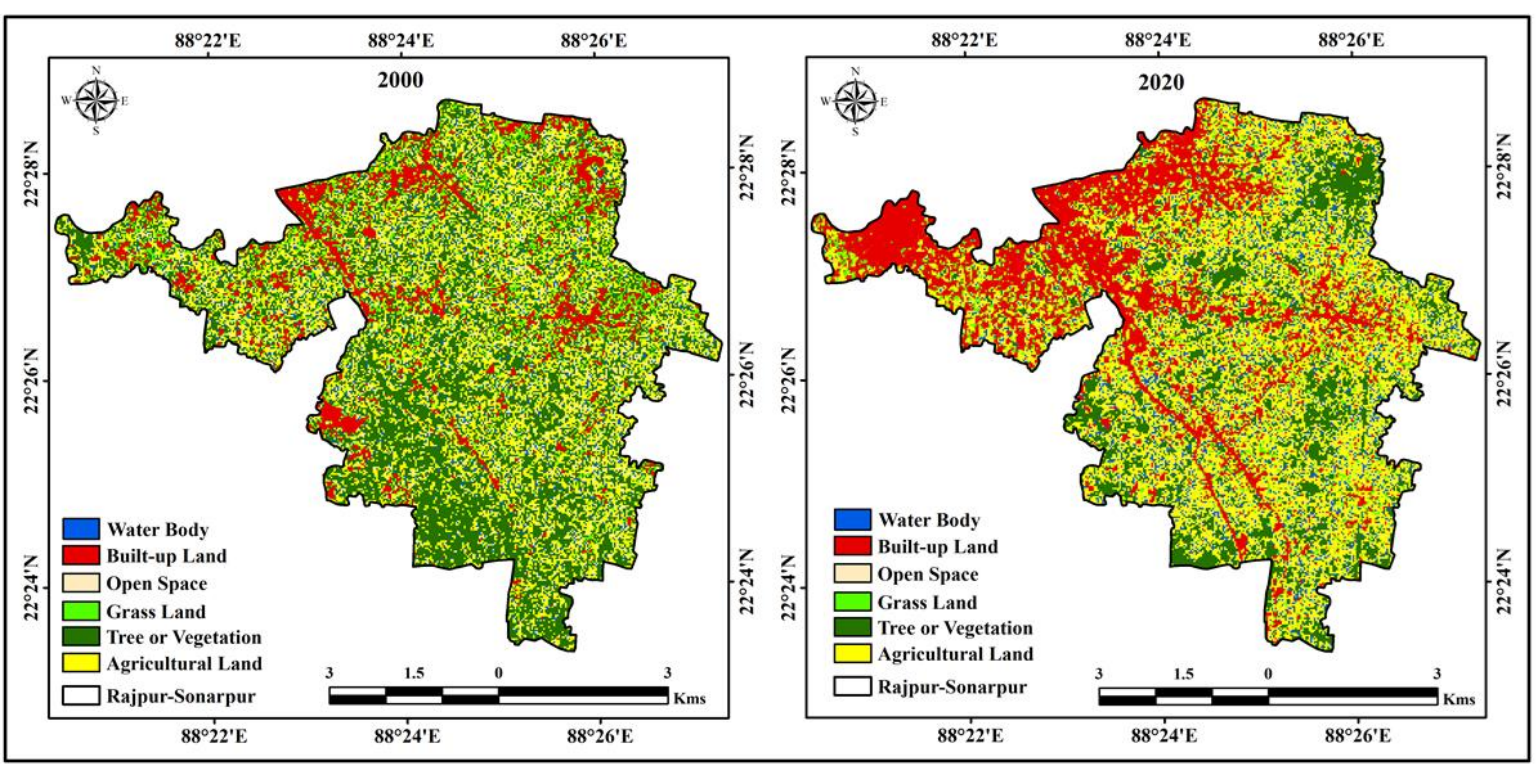

Figure 3. Land used and land cover classification maps of the study area. 


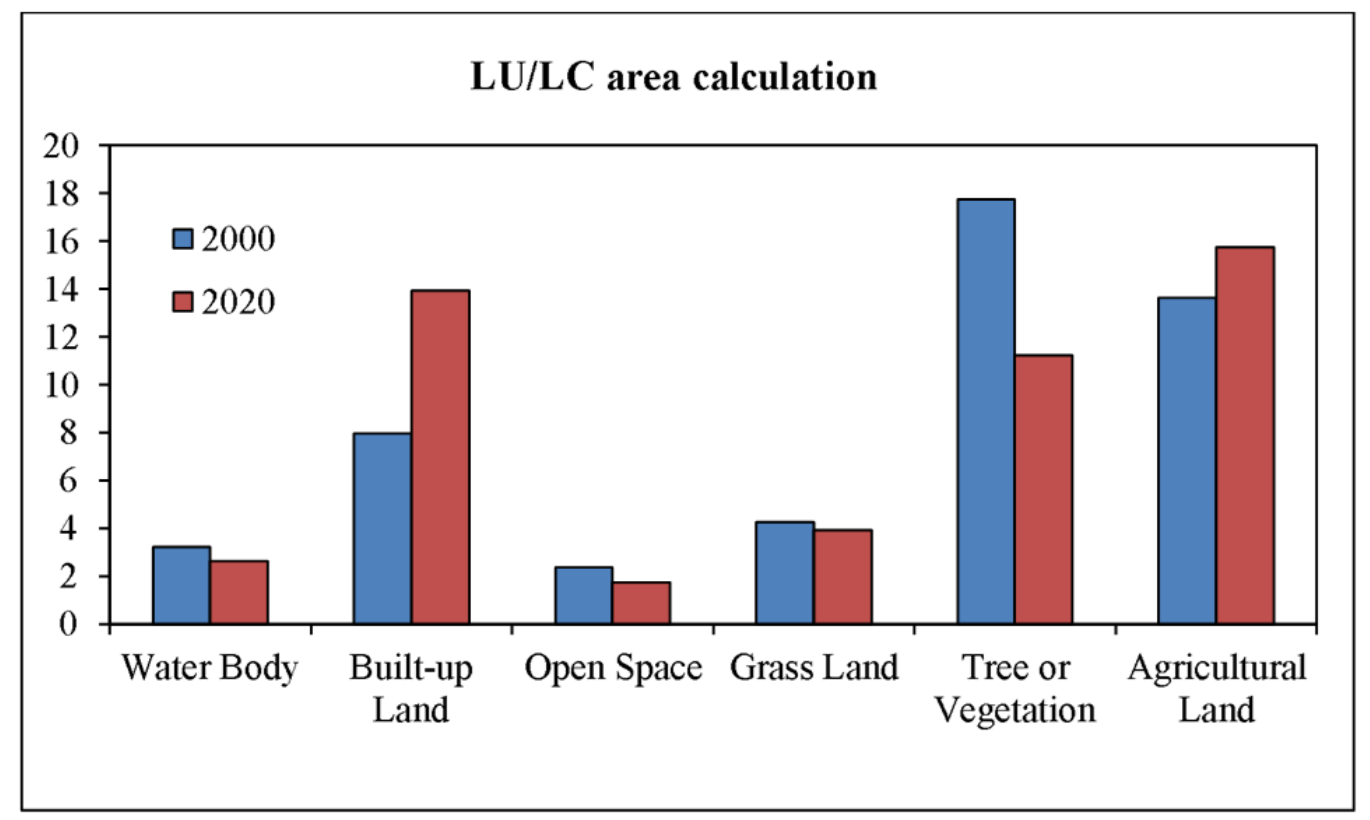

Figure 4. Area calculation of different LULC classes.

Table 6 was shown the statistical representation of LULC classes. Water bodies were decreased $0.6 \mathrm{~km}^{2}$ area and the area was located in north, north-east and north-west parts of this area. In the year 2000, the water body was shown $3.24 \mathrm{~km}^{2}$ and after urban expansion, the water bodies located $2.64 \mathrm{~km}^{2}$. The urban cooling was increased due to high vegetation and water body area, but vegetation and water bodies were lost due to urban expansion in Rajpur-Sonarpur Municipality. The vegetation area was located $17.75 \mathrm{~km}^{2}$ in the year 2000 and after urban expansion, the vegetation area located $11.23 \mathrm{~km}^{2}$, around $6.52 \mathrm{~km}^{2}$ area was converted into built-up land and agricultural land. The built-up land has a significant level of change around $12.16 \%$ of areas have been increased due to anthropogenic activities. The built-up area was located $7.96 \mathrm{~km}^{2}$ area in 2000 and after that built-up area has been increased total by $13.95 \mathrm{~km}^{2}$ in 2020 (Table 6).

Table 6. Area calculation of different LULC classes (2000 and 2020).

\begin{tabular}{|c|c|c|c|c|}
\hline \multirow{2}{*}{ Class name } & \multicolumn{2}{|c|}{ Area in km² } & \multicolumn{2}{c|}{$\begin{array}{c}\text { Area in Percentage } \\
(\%)\end{array}$} \\
\hline Survey Year & 2000 & 2020 & 2000 & 2020 \\
\hline Water Body & 3.24 & 2.64 & 6.78 & 5.36 \\
\hline Built-up Land & 7.96 & 13.95 & 16.16 & 28.32 \\
\hline Open Space & 2.37 & 1.75 & 4.81 & 3.55 \\
\hline Grass Land & 4.28 & 3.93 & 8.69 & 7.98 \\
\hline Tree or Vegetation & 17.75 & 11.23 & 36.04 & 22.8 \\
\hline Agricultural Land & 13.65 & 15.75 & 27.72 & 31.98 \\
\hline Total & 49.25 & 49.25 & 100 & 100 \\
\hline
\end{tabular}

The LULC classes were classified to identify the different land use and land cover area. Google earth and field survey data were used for LULC classes and accuracy assessment. Flats, urban amenities like shopping malls, city centers, and other amenities were built for urban development, but that area is not well planned and increased the thermal variation, heat stress, vegetation degradation, population pressure, and traffic jam. Air pollution is increased due to urban expansion, industrial and transportation development. This air pollution was increased the public health-related problem like asthma, respiratory infarction, lung cancer, and many other health emergencies. The northern parts were a huge amount of urban expansion and vegetation loss due to population pressure and transformation accessibility. The northern parts were significantly developed because the megacity Kolkata is joint with the north part of Rajpur-Sonarpur Municipality. The development of new 
urban amenities, flats, and roads are increased over the study area and similarly decreased the vegetation land and open spaces.

\subsection{Significant of LULC change in other classes}

Changes in land use and land cover may not be the manifestation of soil erosion or land degradation. If the land use and land cover classes are fast transformations into farmland, barren land, and fertile soil is more massive erosion and degradation, without vegetation area. The classified LULC image identified changes in different LULC classes within 2000 and 2020 in terms of the water bodies, open spaces, vegetation area, and agricultural land that were transformed into a settlement area. This rate of changes in land use and land cover exposes this area to severe erosion, land degradation, land subsidence, and groundwater scarcity.

Ethiopia is currently witnessing land degradation and soil erosion due to the rapid transformation of agricultural land into a steeper slope. Land use and land cover alteration have a significant impact on soil erosion, sedimentation, surface runoff, flood, drought, land degradation, biodiversity, migration, and agricultural productivity. The metro expansion in the study area has subjected the area to huge changes in land use and land cover and the related environmental consequences. Urban expansion influences the others LULC classes and the anthropogenic activities were changing the vegetation and agricultural land. The urban settlement was changed the $15 \%$ vegetation area, $5 \%$ of agricultural land, and $25 \%$ of grass land in the study area from 2000 to 2020 . The urban expansion change is located in the Sonarpur railway station area, site of National Highway, northern parts of this study area. Rapid urban expansion can have triggered the natural environment and changed the ecosystem in the study area. Water bodies were decreased and converted into built-up land and other urban amenities.

\subsection{Reason of LULC change}

Changes in the dynamics of land use and land cover can be attributed to several social and natural factors; for instance, population change is the most contributing factor to changes in LULC. Human activity such as the construction of commercial, industrial, and residential areas adds to land use. These activities are driven by rapid population growth and have impacted the rate of changes in LULC. The increased urbanization of the rural-urban fringe areas over the years has also caused changes in the dynamics of land use and land cover; most nuclear families are desperately in need of housing areas. Increased population has also reduced the available land and vegetation area, thereby causing a significant change in land use, land cover, and land subsidence. Figure 5 showed that the vegetation or green spaces decreased in the study area. A huge amount of urban expansion and other urban amenities were influenced the vegetation area and decreased the vegetation area because of anthropogenic activities and climate change.

Figure 6 showed that the built-up land expansion in the study area due to urban expansion and industrialization. High urban green space is increased the oxygen balance, decreased thermal variation, heat stress, and air pollution in the study area but the overwhelming population changed the entire region and increased the health emergency in that area.

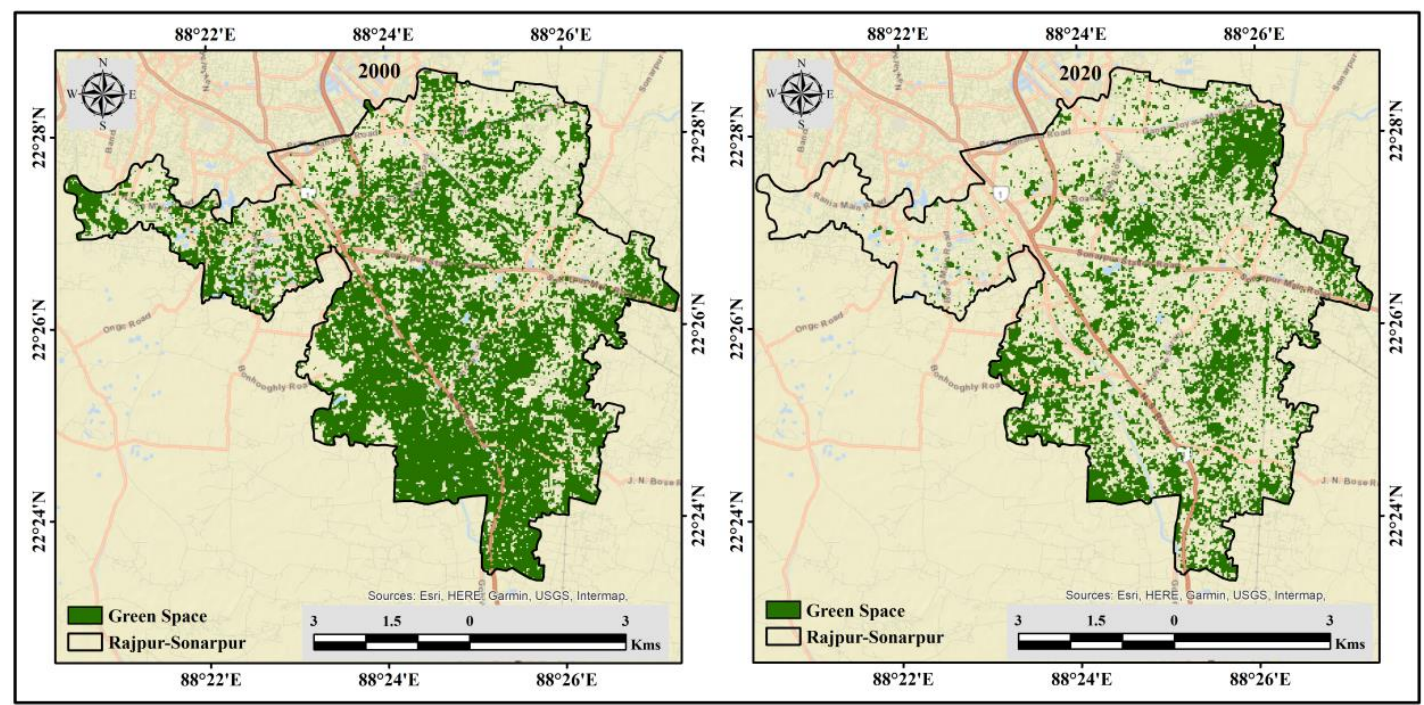

Figure 5. The vegetation condition of the study area. 


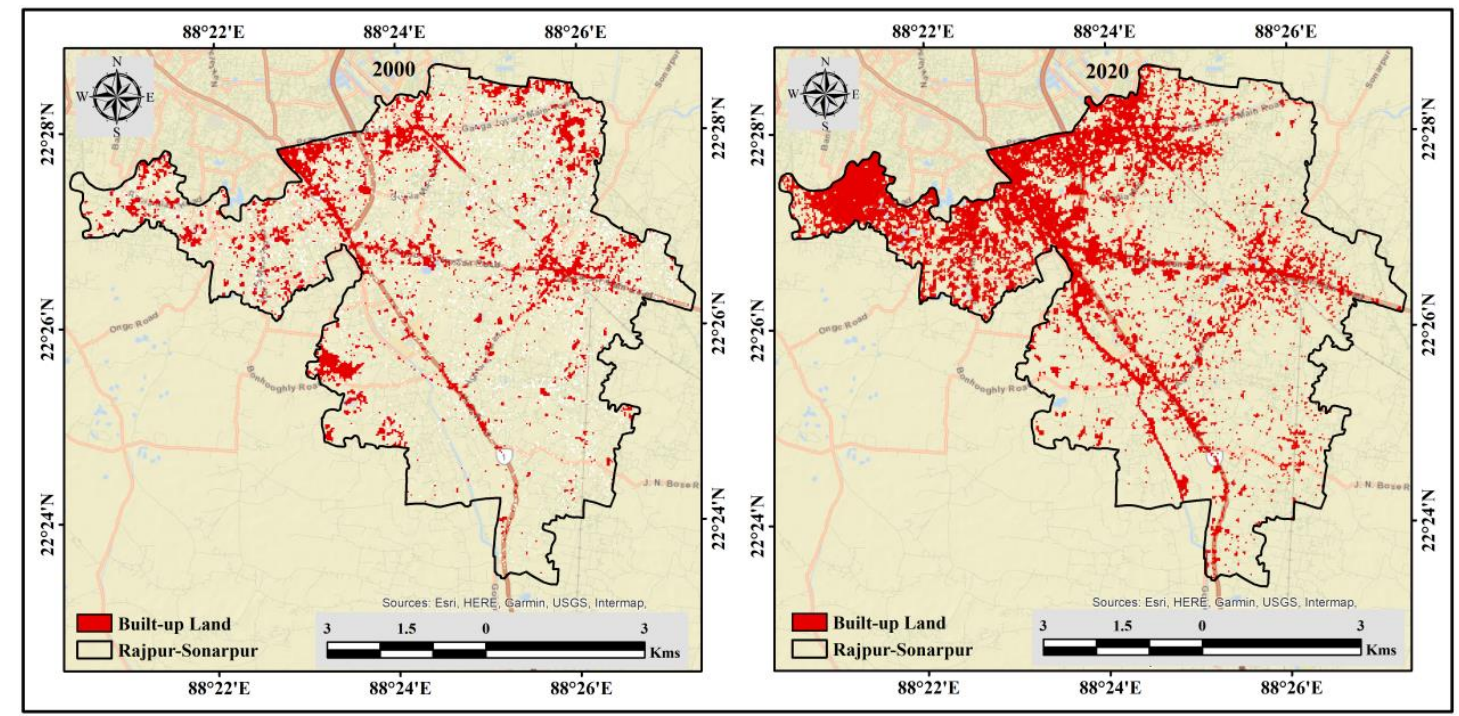

Figure 6. Urban expansion of the study area.

Halder et al. [34] have already built hospital site suitability in the Rajpur-Sonarpur Municipality because of population and hospital ratio are low in the study area. Unplanned built-up expansion and population pressure are needed heath facilities, but this area has not a proper hospital ratio. The people were travelled towards Kolkata and other areas for health-related problems.

\subsection{Topographical distribution of LST}

The topographical distribution of Land surface temperature (LST) was showed the temperature variation in Rajpur-Sonarpur municipality. Figure 7 shows that the LST map of Rajpur-Sonarpur Municipality. The urban expansion and vegetation degradation were the main reason for the LST variation of this area. During twenty years, $7^{\circ} \mathrm{C}$ temperature was increased due to urban expansion, population pressure, transportation accessibility, and other urban amenities. The annual average temperature has been increased by around $0.35^{\circ} \mathrm{C}$ and increased the urban heat stress due to vegetation degradation. The highest and lowest values of LST were $27.94{ }^{\circ} \mathrm{C}$ and $22.816^{\circ} \mathrm{C}$ in the year 2000. The highest and lowest values of LST were $34.91{ }^{\circ} \mathrm{C}$ and $26.02{ }^{\circ} \mathrm{C}$ in the year 2020 .

The study area has experienced significant expansion and as such, has witnessed great differences in temperature in different parts. For instance, the temperature difference in the central, northern, and south-eastern regions is high due to the high rate of human activities. The variation in the temperature of the earth's surface and the spatial distribution of the study region for the years $2000-2020$ are depicted in Figure 7. Most of the agricultural and vegetated lands in the study area have been converted to construction sites. The temperature of an area controls its vegetation. For the study area, the Spatio-temporal distributions of LST for the year 20002020 were acquired using remote sensing technique (Landsat 5 TM and 8 OLI/TIRS) based on the notified equation. In this map, the red and yellow colours represent the highest and lowest temperatures of the region, respectively. The figure showed that the area has experienced an increase in LST and heat stress due to the impact of climate change on the area. The temperature variations in the study area were also captured in the LST maps. 


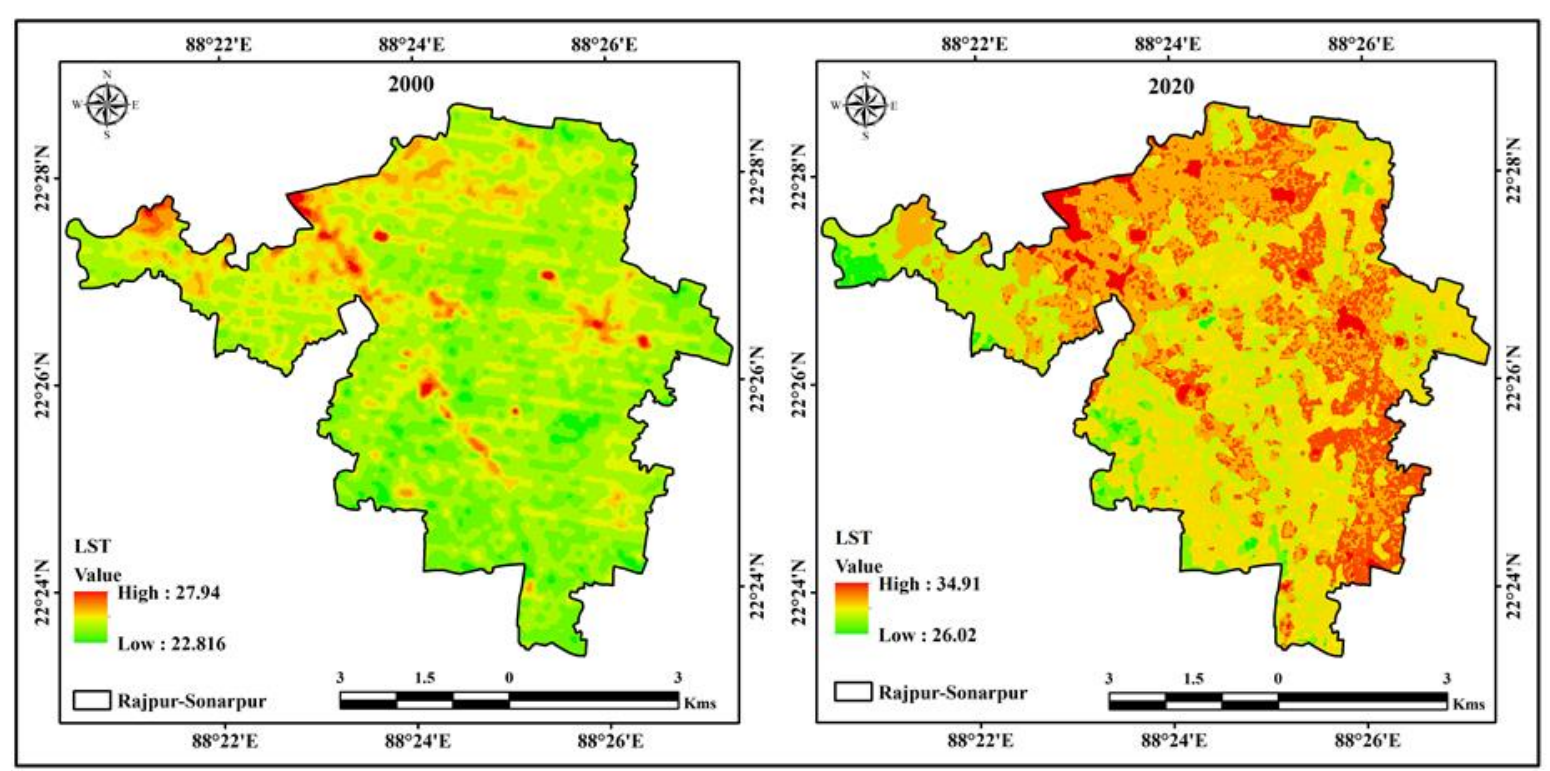

Figure 7. Land surface temperature (LST) maps of different periods (2000 and 2020).

\subsection{Special indicator}

In this study, two spectral indicators have been used, which were Normalized Different Vegetation Index (NDVI) and Normalized Different Built-up Index (NDBI). Two different spectral indicators have been used because of vegetation and built-up area change analysis using an index. The Rajpur-Sonarpur area is the most vegetation and agricultural land located in some decades but after metro expansion towards the northern part of this area, transportation accessibility is increased, which indicated that the vegetated and agricultural land have been decreased and built-up land increased in north, north-west and north-east and central area. The built-up index showed that the urban expansion of two different years' images. Figure 8 shows that the NDVI map, which was indicated that the vegetation change scenario of this study area. The highest value of NDVI shows 0.53 but after twenty years, the NDVI highest value was 0.44 , which was indicated that the vegetation area has been decreased due to anthropogenic activities and urban expansion. South, south-west, and central parts of this area have been decreased huge amount of vegetation area and converted into built-up land and agricultural land (Figure 8).

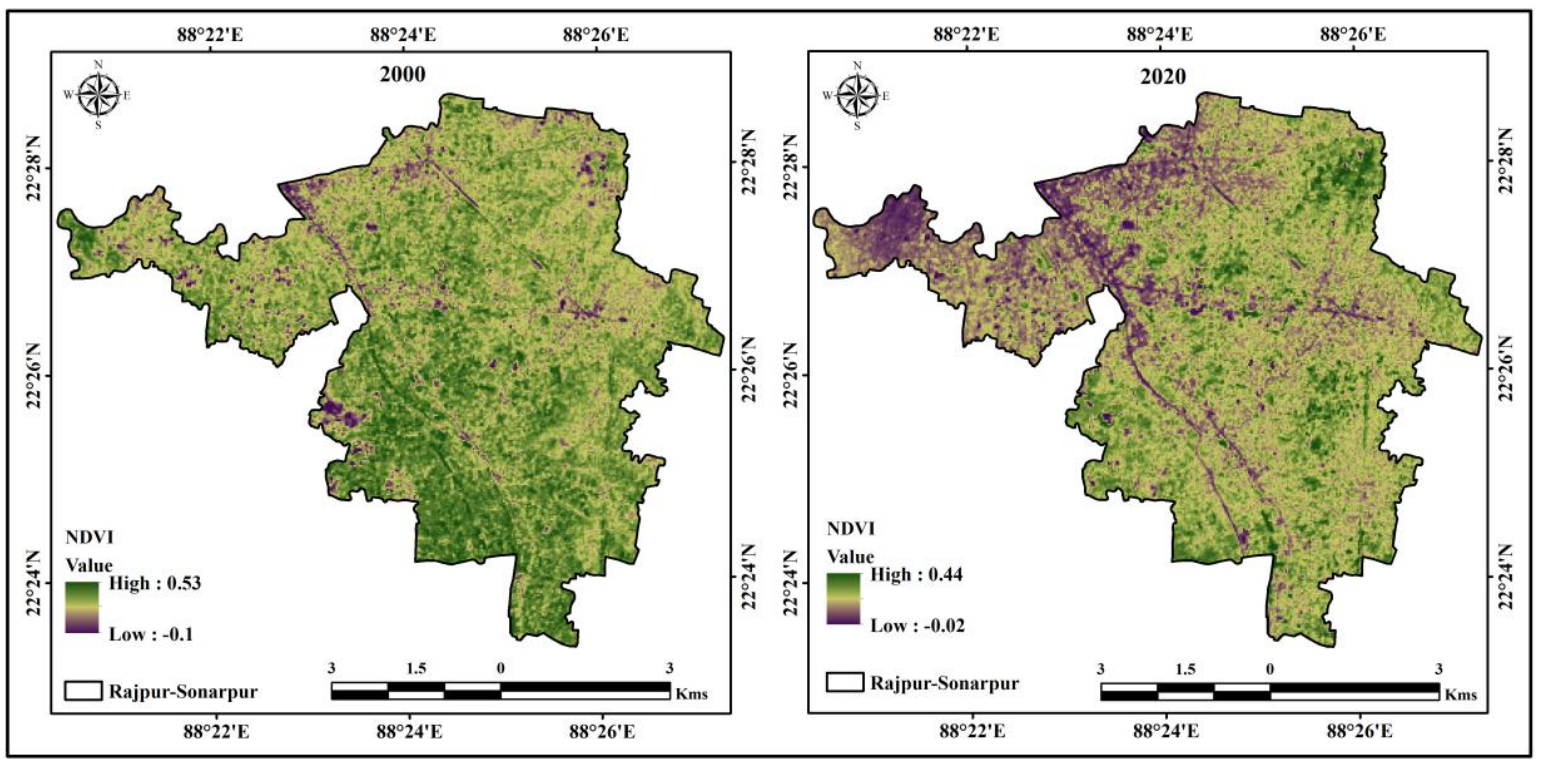

Figure 8. Normalized Different Vegetation Index (NDVI) of different periods (2000 and 2020). 
Figure 9 showed that normalized different built-up indexes (NDBI). The built-up area has been increased most of the area on Rajpur-Sonarpur municipality area. The north, north-east, north-west, and central part of this area have been a huge amount of built-up area alteration due to population pressure, urban expansion, and other anthropogenic activities. In the year o of 2000, the highest value of NDBI showed that 0.35 but after twenty years the highest value showed that 0.57 , which was indicated that the built-up expansion over the study area.

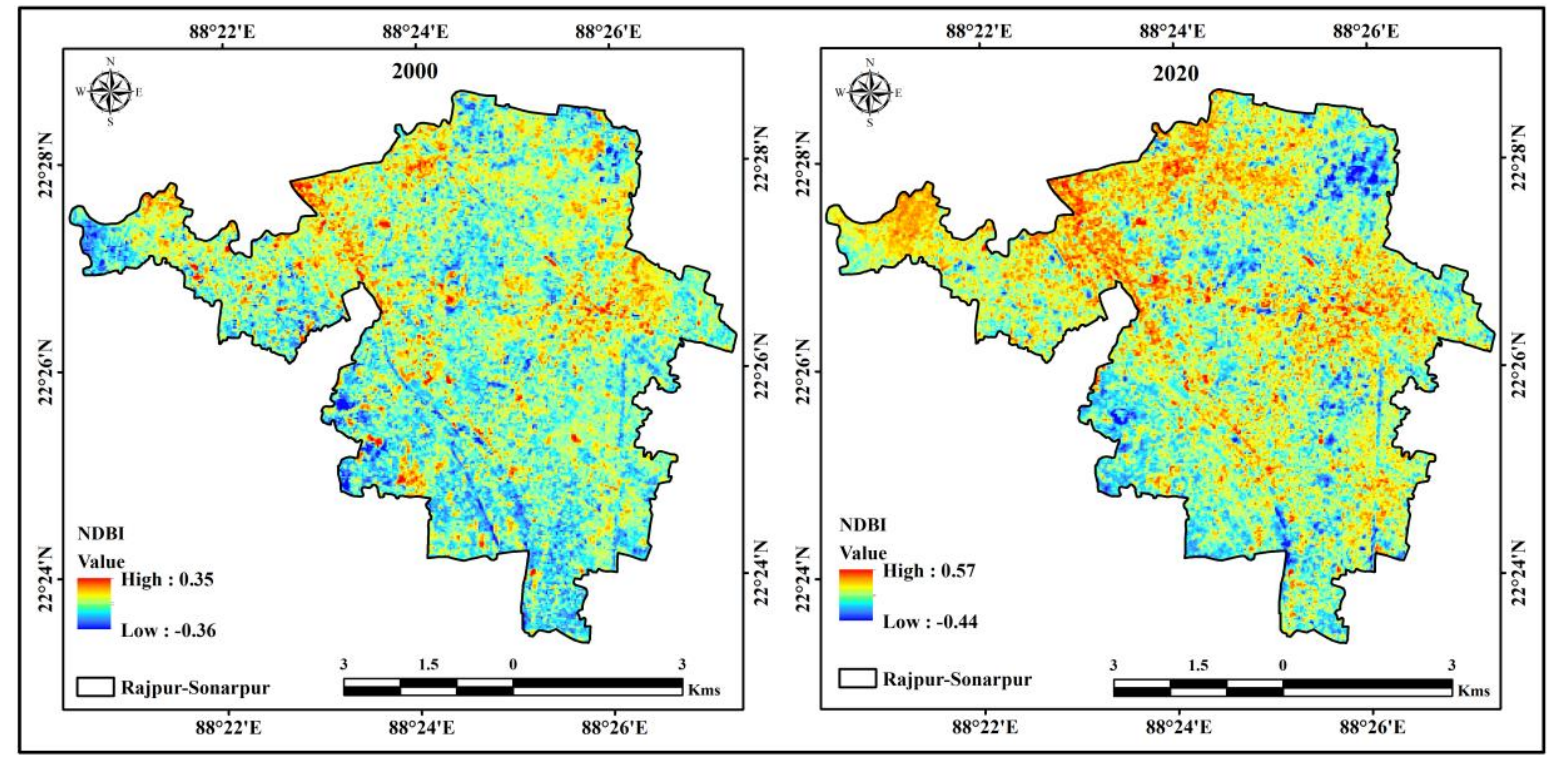

Figure 9. Normalized Different Built-up Index (NDBI) of different periods (2000 and 2020).

The megacity Kolkata is the nearest city of this municipality and Rajpur-Sonarpur municipality is under Kolkata Metropolitan Development Authority (KMDA). The fastest-growing city Kolkata has a business hub, industrial work, hospital facility, and transportation accessibility area, where facilities have been increased and people have used the facilities of their daily need. Kolkata is densely populated and after that, the peripheral parts of this area have been developed and urban areas are expanded towards rural and fringe areas. The results are urban expansion, losses of vegetation and agricultural land, groundwater shortage due to low infiltration rate, urban heat stress, and decrease in oxygen level. Figure 10 showed that the decadal change of different land use and land cover classes in the last twenty years. The Agricultural land, vegetation has been decreased the similarly built-up land has been increased on this area.

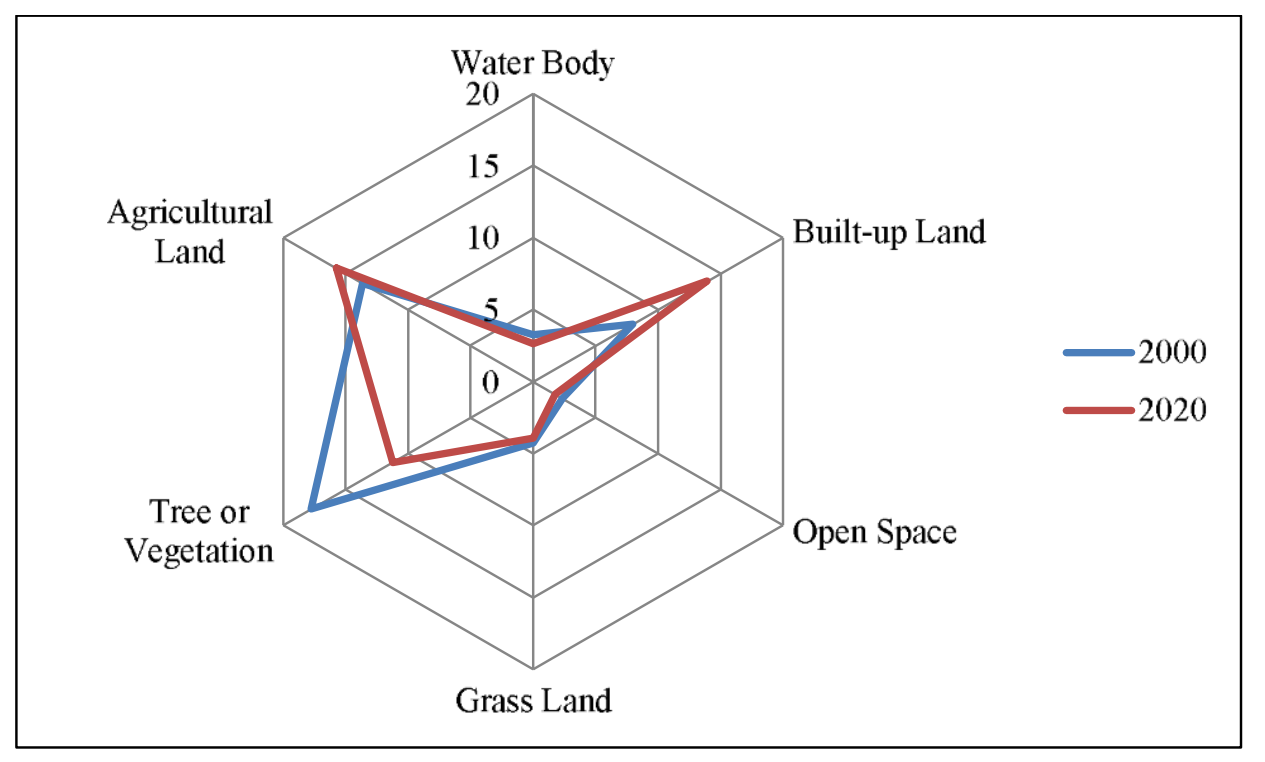

Figure 10. The decadal change of different land use and land cover classes in the last twenty years. 
The limitation of this study was Landsat data is 30-meter resolution, so that pixel-based classification technique was some limitation because different classes were located in the same pixel. Future studies are generally needed like groundwater potential zone identification, urban green space, air pollution, noise pollution, urban heat stress, and transportation-related work. Also, this study is helpful for the urban planners, policymakers, administrators, and other stakeholders for better planning of this area and building sustainable urban development.

\subsection{Urban green space scenario}

The classification results showed that the vegetation cover change area in the different periods in the study area. The results were clearly shown that the vegetation area was converted into the built-up area and other urban amenities. Vegetation area has been increased the healthy life but overwhelming population cut down the vegetation area and converted into an urban area. In the central parts, north, north-east and many parts of northwestern parts were densely populated in last ten years. Grass land and tree-covered area have been converted into urban amenities. The urban green space area was significantly changed due to urban expansion. The green space change maps were clearly shown the grass land and tree-covered area were a huge amount fluctuated due to anthropogenic activities and urban expansion. The road site trees, and grass land were vastly converted into built-up land. The implementation strategies are needed for heat variation during the summer season over the study area. planning tree, roadside tree plantation, rooftop tree plantation is the best work for civilian for decreased the heat stress over the study area and maintain the balance of oxygen level.

\subsection{Urban thermal condition}

Urban areas are mostly heterogeneous and population pressure, infrastructural development, and industrial work were increased heat stress, thermal variation, and climate change. The global climatic condition has been increased the sea level rise, vegetation degradation, heat stress, and coastal vulnerability. Urban areas are also influence by climate-changing conditions. Urban heat island (UHI) is affected by the thermal variation and increased heat stress in the Rajpur-Sonarpur Municipality area. Two types of indices are used in this study for identifying the urban heat stress-related information. Urban heat island (UHI) and Urban thermal field variation index (UTFVI) are used in this study. The overwhelming population pressure and infrastructural developments are increased vegetation losses and groundwater vulnerability. Thermal stress also increased due to urban expansion.

Fringe areas are also influenced by urban expansion and population pressure. Rajpur-Sonarpur municipality is the peripheral part of the Kolkata megacity. The northern parts of the study area are mostly connected by megacity Kolkata and similarly, the heat stress is increased in this location. Agricultural land and vegetation are decreased due to anthropogenic activities and climate change conditions. Figures 11 and 12 are used for monitoring the UHI and UTFVI in the Rajpur-Sonarpur municipality area. Figure 11 shows that the UHI is increased in the last twenty years. In the initial phase (2000) the UHI is located at 4.47 which is an increase of 7.94. The highly affected areas are the north, north-east, and south-eastern parts of the study area. The megacity Kolkata is expanded towards southern parts, which are the northern parts of the study area. Densely urban buildings are increased the thermal variation in the study area. Figure 12 shows that the UTFVI in Rajpur-Sonarpur municipality. The UTFVI is used for monitoring the climate change affected in local ecological conditions which are affected by the global climate change. The heat stress also influences the ecological condition of the study area. The highest values of UTFVI are 0.1114 (2000) and 0.1562 (2020) respectively. These indices indicate the heat stress and ecological condition in Rajpur-Sonarpur Municipality. 


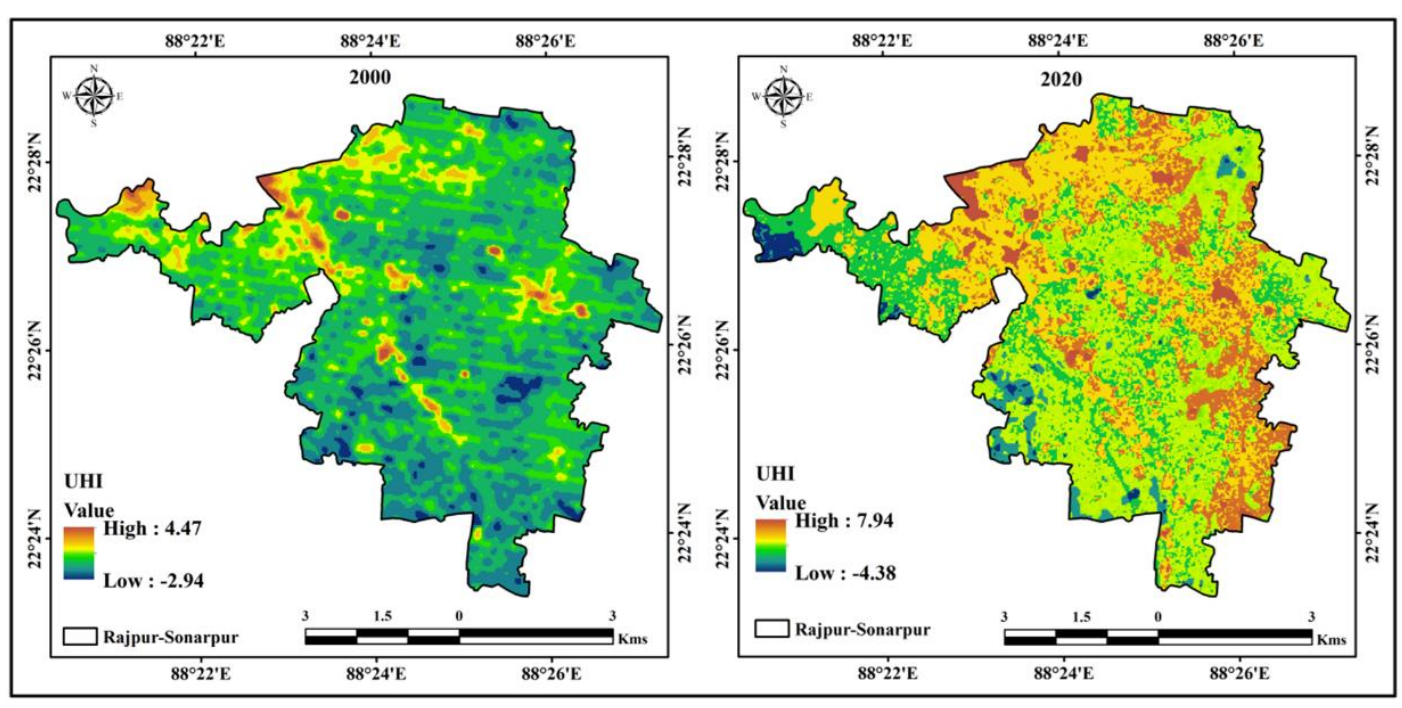

Figure 11. UHI in the Rajpur-Sonarpur Municipality area: left) The year 2000, right) The year 2020.

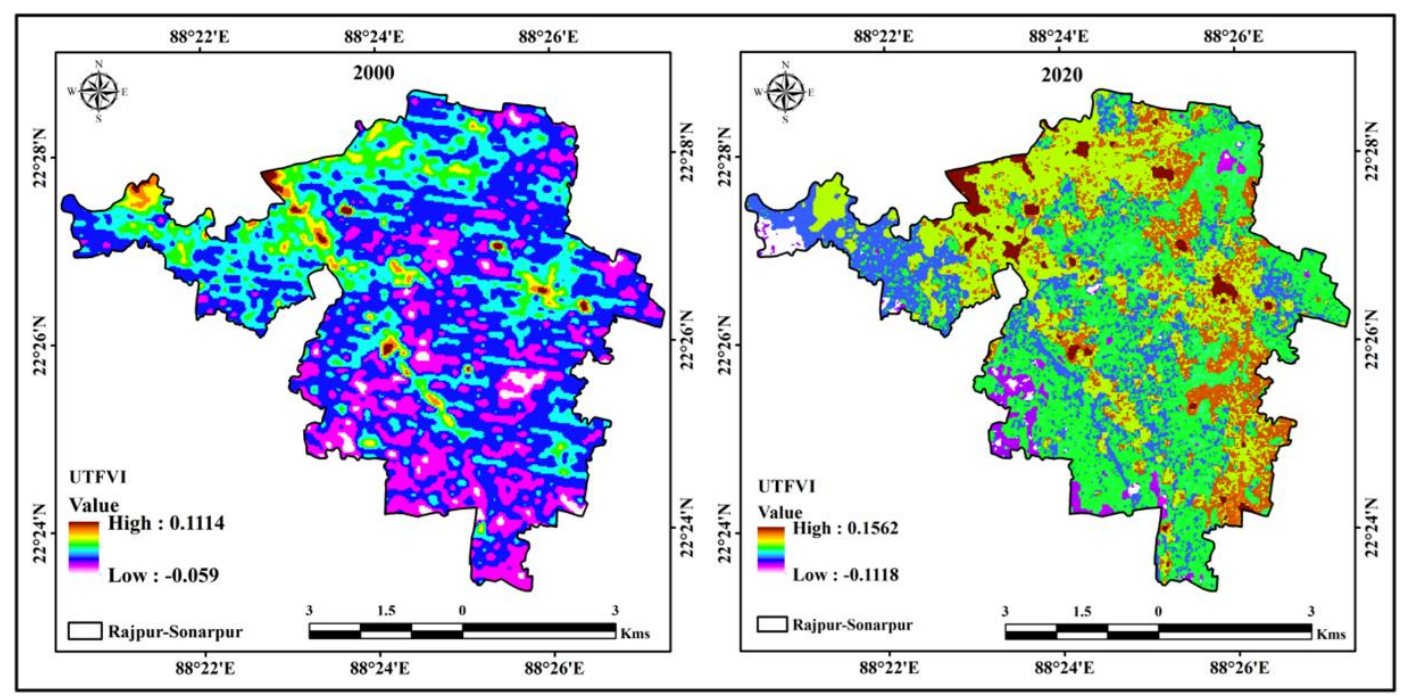

Figure 12. UTFVI in the Rajpur-Sonarpur Municipality area: left) The year 2000, right) The year 2020.

\section{Conclusion}

The Rajpur-Sonarpur municipality is the peripheral part of the megacity Kolkata. Also, some parts of this area are under garter Kolkata. Due to metro station, railway station connectivity, this area is developed rapidly and increased the built-up area similarly the vegetation and agricultural land has been decreased due to population pressure and urban expansion. North, north-east, north-west, and near railway station areas were mostly populated in some decades. Transportation accessibility can join the local business hub Kolkata, which was increased the job opportunities over an area. Agriculture is the main occupation of the people of this area, but after transportation development, urban expansion, and conversion into panchayet to the municipality, this area was developing rapidly and increased the built-up land and other urban amenities. Due to the urban expansion of this area, thermal variation was increased because of vegetation definitely and pollution is increased, which is developed the urban heat stress over the area. Sonarpur railway station is directly joint with the Sealdha station, which is the major railway junction of Kolkata. Many people travel by rail or bus to join the megacity Kolkata.

Due to urban expansion, this area is facing a huge amount of vegetation degradation and increased air pollution, oxygen deficiency, heat stress, and public health-related problems. The built-up area has been increased rapidly and vegetation and agricultural and have been decreased due to anthropogenic activities and urban expansion. The railway station has increased the opportunities to build small industries and connect to 
the main city Kolkata. Urban green space also decreased due to urban expansion, basically north, northeast, northwest, Sonarpur railway station, and Rajpur area. The overwhelming population can change the entire area and the vegetation area has been decreased, which is increased the thermal variation, heat stress, climate change, and environmental degradation. These study results are helpful for the urban planners, policymakers, administrative and other stakeholders to build sustainable development of the Rajpur-Sonarpur Municipality area.

Acknowledgments: We would like to thank Vidyasagar University to support this research. We are also thankful to the Local Government body for our field data collection and other necessary secondary data collection. We also express our gratitude to the United States Geological Survey Department for providing freely satellite data.

Conflict of Interest: On behalf of all authors, the corresponding author states that there is no financial or non-financial interest to disclose.

Funding: There is no financial support for this research.

\section{References}

[1] X. Yang and I. Khan, "Dynamics among economic growth, urbanization, and environmental sustainability in IEA countries: the role of industry value-added," Environ. Sci. Pollut. Res., pp. 1-12, 2021.

[2] M. Alamgir et al., "Evaluating severity-area-frequency (SAF) of seasonal droughts in Bangladesh under climate change scenarios," Stoch. Environ. Res. Risk Assess., 2020.

[3] X.-Y. Jin et al., "Impacts of climate-induced permafrost degradation on vegetation: A review," Adv. Clim. Chang. Res., vol. 12, no. 1, pp. 29-47, 2021.

[4] L. Chen, R. Sun, and H. Liu, "Research progress of ecological environment effect in the evolution of urban landscape pattern," Acta Ecol Sin, vol. 33, no. 4, pp. 1042-1050, 2013.

[5] H. Li et al., "Corrections to "Using Land Long Term Data Records to Map Land Cover Changes in China over 1981--2010’ [Apr 17 1372-1389],” IEEE J. Sel. Top. Appl. Earth Obs. Remote Sens., vol. 12, no. 4, pp. 1333-1334, 2019.

[6] E. Yirsaw, W. Wu, X. Shi, H. Temesgen, and B. Bekele, "Land Use/Land Cover Change Modeling and the Prediction of Subsequent Changes in Ecosystem Service Values in a Coastal Area of China, the Su-Xi-Chang Region," Sustainability, vol. 9, no. 7, p. 1204, 2017.

[7] E. Tasser, G. Leitinger, and U. Tappeiner, "Climate change versus land-use change - What affects the mountain landscapes more?," Land use policy, vol. 60, pp. 60-72, 2017.

[8] U. Schirpke, M. Kohler, G. Leitinger, V. Fontana, E. Tasser, and U. Tappeiner, "Future impacts of changing landuse and climate on ecosystem services of mountain grassland and their resilience," Ecosyst. Serv., vol. 26, pp. 7994, 2017.

[9] B. Rimal, "Urbanization and the Decline of Agricultural Land in Pokhara Sub-metropolitan City, Nepal," J. Agric. Sci., vol. 5, no. 1, 2012.

[10] B. Nath, Z. Wang, Y. Ge, K. Islam, R. P. Singh, and Z. Niu, "Land Use and Land Cover Change Modeling and Future Potential Landscape Risk Assessment Using Markov-CA Model and Analytical Hierarchy Process,” ISPRS Int. J. Geo-Information, vol. 9, no. 2, p. 134, 2020.

[11] S. Ahmed, "Assessment of urban heat islands and impact of climate change on socioeconomic over Suez Governorate using remote sensing and GIS techniques," Egypt. J. Remote Sens. Sp. Sci., vol. 21, no. 1, pp. 15-25, 2018.

[12] R. J. Corner, A. M. Dewan, and S. Chakma, "Monitoring and Prediction of Land-Use and Land-Cover (LULC) Change," Dhaka Megacity. Springer Netherlands, pp. 75-97, 2013.

[13] A. M. Dewan, M. H. Kabir, K. Nahar, and M. Z. Rahman, "Urbanisation and environmental degradation in Dhaka Metropolitan Area of Bangladesh,” Int. J. Environ. Sustain. Dev., vol. 11, no. 2, p. 118, 2012.

[14] H. Han, C. Yang, and J. Song, "Scenario Simulation and the Prediction of Land Use and Land Cover Change in Beijing, China," Sustainability, vol. 7, no. 4, pp. 4260-4279, 2015.

[15] B. Halder, P. Banik, and J. Bandyopadhyay, "Mapping and monitoring land dynamic due to urban expansion using geospatial techniques on South Kolkata," Saf. Extrem. Environ., vol. 3, no. 1, pp. 27-42, 2021.

[16] S. A. Salman et al., "Projection of Agricultural Water Stress for Climate Change Scenarios: A Regional Case Study of Iraq," Agriculture, vol. 11, no. 12, p. 1288, 2021.

[17] T. J. Chandler, "Urban Climatology and Urban Planning," Geogr. J., vol. 142, no. 1, p. 57, 1976.

[18] D. A. Quattrochi and R. E. Pelletier, "Remote Sensing for Analysis of Landscapes: An Introduction," Ecological Studies. Springer New York, pp. 51-76, 1991.

[19] T. R. OKE, "The energetic basic of the urban heat island," Q. J. R. Meteorol. Soc., vol. 108, no. 455, pp. 1-24, 1982.

[20] R. Yao, L. Wang, X. Huang, W. Gong, and X. Xia, "Greening in Rural Areas Increases the Surface Urban Heat 
Island Intensity," Geophys. Res. Lett., vol. 46, no. 4, pp. 2204-2212, 2019.

[21] C. N. Mundia and M. M. James, "Dynamism of land use changes on surface temperature in Kenya: a case study of Nairobi City," 2014.

[22] R. Amiri, Q. Weng, A. Alimohammadi, and S. K. Alavipanah, "Spatial-temporal dynamics of land surface temperature in relation to fractional vegetation cover and land use/cover in the Tabriz urban area, Iran," Remote Sens. Environ., vol. 113, no. 12, pp. 2606-2617, 2009.

[23] Q. Weng, D. Lu, and J. Schubring, "Estimation of land surface temperature-vegetation abundance relationship for urban heat island studies," Remote Sens. Environ., vol. 89, no. 4, pp. 467-483, 2004.

[24] S. Kato and Y. Yamaguchi, "Analysis of urban heat-island effect using ASTER and ETM+ Data: Separation of anthropogenic heat discharge and natural heat radiation from sensible heat flux," Remote Sens. Environ., vol. 99, no. 1-2, pp. 44-54, 2005.

[25] A. A. Zemba, "Analysis of urban surface biophysical descriptors and land surface temperature variations in Jimeta City, Nigeria,” Glob. J. Hum. Soc. Sci., vol. 10, no. 1, pp. 19-25, 2010.

[26] K. A. Ishola, E. C. Okogbue, and O. E. Adeyeri, "Dynamics of surface urban biophysical compositions and its impact on land surface thermal field," Model. Earth Syst. Environ., vol. 2, no. 4, pp. 1-20, 2016.

[27] A. D. Mehr and O. Akdegirmen, "Estimation of Urban Imperviousness and its Impacts on Flashfloods in Gazipaşa, Turkey," Knowledge-Based Eng. Sci., vol. 2, no. 1, pp. 9-17, 2021.

[28] X. Dai and S. Khorram, "Development of a new automated land cover change detection system from remotely sensed imagery based on artificial neural networks," IGARSS'97. 1997 IEEE International Geoscience and Remote Sensing Symposium Proceedings. Remote Sensing - A Scientific Vision for Sustainable Development. IEEE.

[29] B. Halder, J. Bandyopadhyay, and P. Banik, "Evaluation of the Climate Change Impact on Urban Heat Island Based on Land Surface Temperature and Geospatial Indicators," Int. J. Environ. Res., 2021.

[30] K. Jia, X. Wei, X. Gu, Y. Yao, X. Xie, and B. Li, "Land cover classification using Landsat 8 operational land imager data in Beijing, China," Geocarto Int., vol. 29, no. 8, pp. 941-951, 2014.

[31] D. Lu, S. Hetrick, E. Moran, and G. Li, "Application of time series Landsat images to examining land-use/landcover dynamic change," Photogramm. Eng. Remote Sensing, vol. 78, no. 7, p. 747, 2012.

[32] A. Alam, M. S. Bhat, and M. Maheen, "Using Landsat satellite data for assessing the land use and land cover change in Kashmir valley," GeoJournal, vol. 85, no. 6, pp. 1529-1543, 2020.

[33] A. Erener, S. Düzgün, and A. C. Yalciner, "Evaluating land use/cover change with temporal satellite data and information systems," Procedia Technol., vol. 1, pp. 385-389, 2012.

[34] B. Halder, J. Bandyopadhyay, and P. Banik, "Assessment of hospital sites' suitability by spatial information technologies using AHP and GIS-based multi-criteria approach of Rajpur-Sonarpur Municipality,” Model. Earth Syst. Environ., vol. 6, no. 4, pp. 2581-2596, 2020.

[35] T. W. Meshesha, S. K. Tripathi, and D. Khare, "Analyses of land use and land cover change dynamics using GIS and remote sensing during 1984 and 2015 in the Beressa Watershed Northern Central Highland of Ethiopia," Model. Earth Syst. Environ., vol. 2, no. 4, pp. 1-12, 2016.

[36] Z. Hassan et al., "Dynamics of land use and land cover change (LULCC) using geospatial techniques: a case study of Islamabad Pakistan,” Springerplus, vol. 5, no. 1, 2016.

[37] M. C. Cheruto, M. K. Kauti, P. D. Kisangau, and P. Kariuki, "Assessment of Land Use and Land Cover Change Using GIS and Remote Sensing Techniques: A Case Study of Makueni County, Kenya,” J. Remote Sens. GIS, vol. 05, no. 04, 2016.

[38] D. Lu and Q. Weng, "Use of impervious surface in urban land-use classification," Remote Sens. Environ., 2006.

[39] A. Owojori and H. Xie, "Landsat image-based LULC changes of San Antonio, Texas using advanced atmospheric correction and object-oriented image analysis approaches," in 5th international symposium on remote sensing of urban areas, Tempe, AZ, 2005.

[40] T. V Ramachandra, H. A. Bharath, and S. Vinay, "Land use land cover dynamics in a rapidly urbanising landscape," SCIT J, vol. 13, pp. 1-12, 2013.

[41] H. A. Bharath, M. C. Chandan, S. Vinay, and T. V Ramachandra, "Modelling urban dynamics in rapidly urbanising Indian cities," Egypt. J. Remote Sens. Sp. Sci., vol. 21, no. 3, pp. 201-210, 2018.

[42] S. K. Singh, P. K. Srivastava, S. Szabó, G. P. Petropoulos, M. Gupta, and T. Islam, "Landscape transform and spatial metrics for mapping spatiotemporal land cover dynamics using Earth Observation data-sets," Geocarto Int., pp. 1-15, 2016.

[43] L. Cao, P. Li, L. Zhang, and T. Chen, "Remote sensing image-based analysis of the relationship between urban heat island and vegetation fraction," in International Archives of the Photogrammetry, Remote Sensing and Spatial Information Sciences - ISPRS Archives, 2008.

[44] J. A. Sobrino, N. Raissouni, and Z. L. Li, "A comparative study of land surface emissivity retrieval from NOAA data," Remote Sens. Environ., 2001.

[45] J. C. Semenza et al., "Heat-Related Deaths during the July 1995 Heat Wave in Chicago," N. Engl. J. Med., vol. 335, no. 2, pp. 84-90, 1996. 
[46] A. Rasul, H. Balzter, and C. Smith, "Spatial variation of the daytime Surface Urban Cool Island during the dry season in Erbil, Iraqi Kurdistan, from Landsat 8," Urban Clim., vol. 14, pp. 176-186, 2015.

[47] M. Scarano and J. A. Sobrino, "On the relationship between the sky view factor and the land surface temperature derived by Landsat-8 images in Bari, Italy,” Int. J. Remote Sens., vol. 36, no. 19-20, pp. 4820-4835, 2015.

[48] G. Gutman, C. Huang, G. Chander, P. Noojipady, and J. G. Masek, “Assessment of the NASA-USGS Global Land Survey (GLS) datasets,” Remote Sens. Environ., vol. 134, pp. 249-265, 2013.

[49] D. P. Roy et al., "Landsat-8: Science and product vision for terrestrial global change research," Remote Sens. Environ., vol. 145, pp. 154-172, 2014.

[50] X. Yu, X. Guo, and Z. Wu, "Land Surface Temperature Retrieval from Landsat 8 TIRS - Comparison between Radiative Transfer Equation-Based Method, Split Window Algorithm and Single Channel Method," Remote Sens., vol. 6, no. 10, pp. 9829-9852, 2014.

[51] U. Avdan and G. Jovanovska, "Algorithm for Automated Mapping of Land Surface Temperature Using LANDSAT 8 Satellite Data,” J. Sensors, vol. 2016, pp. 1-8, 2016.

[52] B. Halder, J. Bandyopadhyay, and P. Banik, "Monitoring the effect of urban development on urban heat island based on remote sensing and geo-spatial approach in Kolkata and adjacent areas, India," Sustain. Cities Soc., vol. 74, p. 103186, 2021.

[53] N. Khan et al., "Determination of cotton and wheat yield using the standard precipitation evaporation index in Pakistan," Arab. J. Geosci., vol. 14, no. 19, pp. 1-16, 2021. 